\title{
Mongolian Foreign Policy Implications for Russia and China
}

\author{
V aishali Krishna (India)
}

$\mathrm{T}$

The efforts made by each nation for achieving self-reliance in a situation characterised by ever-increasing inter-dependence and conflict is the most fundamental fact of international relations. It is eventually the "national interest" that the nations seek to protect or achieve in relation to each other. Different nations plan their own course in international relations and arrange their priorities according to their own national interest which has a very important relation with foreign policy with the help of which it tries to realize its goals. The main purpose of foreign policy is to conduct foreign relations to the best possible advantage. ${ }^{1}$ As the national interests of a nation keep changing, their foreign policies also undergo change. Several scholars are of the opinion that the national interests of different nations must be compatible with each other in the interest of global harmony and peace. In that sense, international relations embrace all types of complex activities whether cultural, political or those dictated by foreign policy. It is for each individual state to decide as to what degree of its involvement in its relations with another state would guarantee and safeguard its interest. Thus, foreign policy has both positive and negative aspects: It is positive when it aims at adjusting the behaviour of other states by changing it and negative when it seeks such an adjustment by not changing that behaviour. ${ }^{2}$

There are cases of having very small size of territory as well as small population, yet the states are found to be adopting a very effective foreign policy. In short, "foreign policy is the sum total of decisions taken by a country to regulate the behaviour of other states. Therefore, the international system at any given point of time has direct impact on foreign policies". ${ }^{3}$ This is true to the case of Mongolian foreign policy also. All the developments taking place in Mongolia's drive toward democratic reforms and economic restructuring came after the collapse of the world socialist system and the former Soviet Union that dramatically changed the external situation of Mongolia. In the post-cold war period, the major changes occurred in Mongolia's two neighbouring countries-Russia and China also had a direct impact on its external environment, particularly in terms of security. The reforms and restructuring of the country's internal political, social and economic systems together with a changed geostrategic scenario externally provided it with 
favourable conditions for conducting a foreign policy based on realism and its national interests.

While highlighting the determinants of Mongolian foreign policy the general provisions of the official document entitled as Concept of Foreign Policy of Mongolia declares that "Mongolia's foreign policy shall be based on its national interests, as defined in its Constitution", and that "the country's specific external and internal situation constitutes the basis of determining its foreign policy objectives, principles and priorities." ${ }^{4}$ The document further states that "Mongolia's foreign policy objectives reside in ensuring its independence and sovereignty by following trends of human society's advancement, maintaining friendly relations with all countries, strengthening its position in the international community and forming with influential countries in the region and in the world a network of relationship based on the interdependence of political, economic and other interests." Even Mongolian Foreign Policy Blue Book issued by the Ministry of External Relations of Mongolia in 2000 clearly says that a relatively favourable internal and external environment opened broad perspectives for pursuing an active, innovative and rational foreign policy that "truly upholds Mongolia's national interests, enables to accelerate its economic development and ensure its national security." In that sense, both the internal as well as external factors show its relevance for Mongolia so far as its foreign policy is concerned.

This article, therefore, deals with the evolution of Mongolian foreign policy in the post-Soviet period as well as a shift in its goals and subsequently tries to find out the foreign policy implications for the two physical neighbours - Russia and China in recent times.

\section{Development of Post-Soviet Mongolia's Foreign Policy}

The end of the Cold War provided an opportunity for various nations, particularly in Asia, to experience a complete change in the international order. In other words, as some analysts believe, "it was a return of history in diversity of new and emerging developments". ${ }^{6}$ Another aspect of this changed scenario can be gauged from the fact that it gave enough space to nations to reanalyze the ideological and structural dimension of their policies in political, social, economic and cultural fields. This also meant recognizing the contemporary changes and its sociological implications, making structural readjustment and reshaping the pattern of future growth and development in political-diplomatic spheres. Such changes have found their relevance in case of Mongolia as well. This is more so because the collapse of the former Soviet Union also provided Mongolia a rare opportunity in its history to come out of Soviet grip and become part of the new international order. ${ }^{7}$ Significantly, the new emerging forces of globalization led 
Mongolia to march ahead in search for a new national identity and recast her ties with the external world on a new basis. These processes were further accelerated by the democratic reforms "with stability based on peaceful evolution". ${ }^{8}$ What is remarkable to be noted here is that unlike the Soviet period democratic reforms in Mongolia are now characterized by more flexible and pragmatic solutions to all the existing problems in all spheres of socio-economic and political domains.

Moreover, these reforms paved the way for framing the governmental policies in such a manner that it could benefit Mongolia both internally and externally. ${ }^{9}$ So far as external benefit is concerned Mongolia has been able to pursue the policy of maintaining cordial relations with rest of the countries, particularly in Asia. ${ }^{10}$ Therefore, a well-defined concept was required to be adopted so far as Mongolia's foreign and security policy was concerned. However, the first major change in government policy occurred in terms of a new national identity that took place on 28 November 1991 when Mongolia's State Great Khural (parliament) decided to change the name of the country from the Mongolian People's Republic to simply the Republic of Mongolia, which was done in the new constitution introduced on 12 February 1992. The constitution not only stressed on the adoption of political democracy and the market economy, ${ }^{11}$ but also stipulated that "Mongolia shall adhere to the universally recognized norms and principles of international law and pursue a peaceful foreign policy". ${ }^{12}$

Fundamentally, "it implies that Mongolia has opted for an open foreign policy, free from past ideological constraints". ${ }^{13}$ Besides, it also indicates the realization by the Mongolian policy-makers that Mongolia's national security could only be ensured by securing international guarantees "through a combination of unilateral, bilateral and multilateral measures". ${ }^{14}$ Therefore, in 1994, the State Great Khural introduced a set of domestic and foreign policy guidelines that, among other things, steered the country onto a new diplomatic course aimed at securing its own independence and sovereignty. The primary objective was to balance its relations with Russia and China. Secondly, Mongolia was interested in promoting its ties with Japan, the U.S., Germany, and other leading industrial countries, and in fostering closer ties with countries of the Asia-Pacific region. Accordingly, it began pursuing an active multilateral diplomatic offensive. While economic development was of course one of the goals Mongolia had in mind with such strategies, gaining prestige for itself in the international community was also on the cards. By pursuing a diversified foreign policy, Mongolia was optimistic to work out on reassuring security arrangements, especially at a time when it was no longer under a protective shield of the Soviet like "big brother".

The need for a fresh independent foreign policy was in fact felt back in 1986 when Gorbachev's Vladivostok initiative sought for withdrawal of Soviet troops from Mongolia. And later this was considered to be "a clear signal to Mongolia 
to examine a whole range of foreign policy options". ${ }^{15}$ Therefore, in 1989 it was realized that the principal motivation driving Mongolia's foreign policy was the preservation of territorial integrity, together with the projection of a substantial measure of political independence. As already pointed out, Mongolia often served as a Soviet proxy, representing the Soviet position when and where needed throughout the Cold War period. However, in the post-Soviet period unlike the newly independent five Central Asian Republics who following their sudden independence faced similar dilemma due to their landlocked geographical position in selecting international partner, Mongolia was able to foresee some of the fallouts and take a more balanced and pragmatic approach to the new global realities to which both domestic and international factors contributed tremendously. The key policy issues revolved around Mongolia included "national interest in the first place, depending upon how constructively the policy and strategy can achieve the defined goals". ${ }^{16}$ Thus, the issue of national security which was actually "directly dependent on the international security" was taken as the most important factor while defining the goals of Mongolia's external relations. For that reason, the national security of Mongolia was divided into global, regional and sub-regional and Mongolian foreign policy has been framed accordingly. Finally, Mongolia came up with its "Multi-Pillared" foreign policy also known as "Multi-Dimensional" or "Omni-directional" foreign policy, the basic tenets of which were spelled out in the three inter-related documents, i.e., Concept of National Security, Concept of Foreign Policy and the Military Doctrine which were adopted by the State Great Khural in July $1994 .{ }^{17}$

In fact, this "Multi-Pillared" foreign policy from the initial stage took an inclusive account of traditional and non-traditional aspects of national security which helped in reshaping Mongolia's external relations on quite a new basis. The basic aim of Mongolia's foreign policy has been to preserve the selfdetermination of the Mongol people, ${ }^{18}$ and to meet Mongolia's national interests, which are "the existence of the Mongolian people and their civilization ... the country's independence, sovereignty territorial integrity ... relative economic independence, sustainable ecological development and national unity." (Concept of National Security, Point 3). Of these the two most important are retaining sovereignty and economic independence. ${ }^{19}$ In addition, Mongolia also pursues a policy of non-intervention in its neighbours' affairs, unless its own interests are jeopardized (Concept of Foreign Policy, Point 9). Hence, in accordance with the 1994 Concept of Mongolia's Foreign Policy the whole policy has been guided by the following directions: ${ }^{20}$

a) Upholding friendly relations with Russia and China shall be priority directions of Mongolia's foreign policy activity. It shall not adopt the line of either country but shall maintain in principle a balanced relationship with both of them and shall promote all-round neighborly cooperation. 
b) Developing friendly relations with highly developed countries of the West and East and creating and bringing to an appropriate level their economic and other interests in Mongolia.

c) Strengthening Mongolia's position in Asia and securing a constructive participation in the political and economic integration process in the region. Within the framework of this objective, greater attention shall be given to Asia and the Pacific region, in particular to North-East and Central Asia.

d) Promoting cooperation with the United Nations and its specialized agencies, and with international financial and economic organizations, including the International Monetary Fund, the World Bank and the Asian Development Bank.

e) Developing friendly relations with countries of the former socialist community, as well as the newly independent states. When developing relations with these countries, a flexible approach will be adopted, reinforcing the positive legacy of past relations while at the same time taking into account the potential of promoting relations in conformity with the new circumstances.

f) Enhancing friendly relations with developing countries and cooperating with them beyond the framework of bilateral relations as much as possible in the solution of common objectives.

\section{Shift in Mongolia's Foreign Policy Concept and its Goals}

From the very beginning of the year 2000, changes witnessed both at the domestic as well as foreign front motivated Mongolian leadership to rethink about revising its existing foreign policy in order to attract foreign partners not only in the politico-strategic field but also in the economic and trade sphere. As such the Mongolian Parliament approved an updated National Security Concept in July 2010 and a revised Foreign Policy Concept in February 2011. Both the documents redefined the new strategic direction of Mongolia's security and foreign policy. In fact, it was on 8 January 2011 that G. Zandanshatar, the Mongolian Minister of Foreign Affairs submitted a draft resolution to the Parliament Speaker D. Demberel on approval of the revised Concept of Foreign Policy of Mongolia. Reportedly, at that time, the Foreign Minister said that "he submitted the draft resolution in conjunction with requirements to increase benefits of external relations and to provide foreign policy with economic content in times of widening foreign relations and cooperation and intensive development of economics. ${ }^{21}$ As per the draft resolution, some clauses on the change of the foreign environment and on some new goals for Mongolia have been added in the revised concept. Besides, new wording has also been reflected in the concept in order to harmonize foreign policy with the concept of national security. Finally, the Mongolian Parliament approved the revised Concept of Mongolia's Foreign Policy on 10 February 
2011, thus making a shift from the existing Concept of 1994. In this regard, on 9 January 1912 during his remarks at a reception with Diplomatic Corps in Ulaanbaatar, Mongolian President Ts. Elbegdorj spoke about the necessity of revising the Foreign Policy Concept. Among others, he also made it clear that protecting the rights and interests of thousands of Mongolian citizens abroad is one of the priorities of Mongolia's foreign policy, which has been included as a whole chapter in the revised Foreign Policy Concept. ${ }^{22}$

It is, however, to be mentioned here that whereas Mongolia's foreign policy for the 1990s was formulated around what Reeves considers as "an omni-enmeshment strategy", its foreign policy from 2000 onwards can best be conceptualised as "an amalgam of omni-enmeshment and balance of influence". ${ }^{23}$ According to Reeves, Mongolia's new foreign policy strategy implicitly identifies China as the country's largest security concern which has been mirrored in Ulaanbaatar's post-2000 foreign policy relations. It is, therefore, evident that although the 2011 Concept does retain relations with China and Russia as a key plank of foreign policy, it dilutes the original importance placed on these relations by affording them equal footing with the need to maintain relations with 'strategically important states', the need to develop closer relations with the country's third neighbours, and the need to increase cooperation with the US. ${ }^{24}$ Such a shift in Mongolia's foreign policy can be understood through various goals set in the revised Foreign Policy Concept. According to the revised Concept, several provisions have been made in political, economic, scientific, technological, cultural and humanitarian fields of foreign policy. ${ }^{25}$

\section{Mongolia's Foreign Policy Strategy towards Russia and China}

Since Mongolia's foreign policy is based on pragmatism, it relies on ongoing international political reality as well as the trends of international economic development. ${ }^{26}$ In this sense, the top priority direction of Mongolia's foreign policy lies in taking an active part in the process of establishing a global multilateral security mechanism. Indeed, as Concept of Foreign Policy stresses, Mongolia's foreign policy aims at ensuring the security and prosperity of the country both internally and externally by "forming with influential countries in the region and in the world a network of relationship based on the interdependence of political, economic and other interests". ${ }^{27}$ The general principles of both the 1994 Concept of Foreign Policy as well as the 2011 revised Concept of Foreign Policy, in part, declare that

(a) While following a policy of creating realistic interest of developed countries in Mongolia, it will seek to avoid becoming overly reliant or dependent on any particular country....; and 
(b) Mongolia will not interfere in the disputes between its neighbouring countries [Russia and China] unless the disputes affect Mongolia's national interests.

Obviously, the geographical location has had a vital impact on the entire spectrum of Mongolia's foreign policy, and so relations with immediate neighboursRussia and China were given a very high priority. But, at the same time, Mongolia declared to have a balanced relationship with both the neighbours. ${ }^{28}$ In the words of the then Mongolian President N. Enkhbayar: "Multi-pillar foreign policy concept is the outcome of our aspirations not to be isolated, but to be open, and it brings about the necessity to develop 'neighbourly' relations with such important players at the international arena as the US, Europe, Japan, India, the UN and others, thus securing the independence of the country." 29 Since the Concept of Foreign Policy puts emphasis on "balanced" or "equidistance" in maintaining relations with Russia and China, principally due to the historical, geographical and economic factors, the policy core is not to adopt the line of either of these two countries but maintain a balanced relationship with both of them. "It specifically underlined", as Oyun Sanjaasuren, the then Minister for Foreign Affairs of Mongolia, pointed out while delivering a lecture at the Marshall Centre, Bavaria, Germany on 8 February 2008, that "a policy of non-involvement and neutrality would be pursued with regard to the disputes that could arise between the two neighbours, unless the latter directly, affected Mongolia's national interests, in which case it would follow its vital interests." 30

Whereas Mongolia now maintains a strategic partnership with Russia and partnership of good neighbourly friendship and cooperation with China, the socalled "third neighbour" policy also forms the part of its multi-pillar foreign policy, "which articulates a policy of balance". ${ }^{31}$ In simple words, the "third neighbour" policy means that Mongolia will no longer be dependent only on one neighbour but rather on as many as countries and international institutions as possible apart from being a part of both Northeast Asia and Central Asia. ${ }^{32}$ Initially, in the mid1990s when no single nation came forward to be understood in real terms as Mongolia's "third neighbour", North East Asia began to be viewed as a region for establishing Mongolia's new relationship that "went beyond economic ties to include political concerns". ${ }^{33}$ Nevertheless, Mongolia tried to forge its relations with a whole community of developed countries in the East and West, mainly with the United States, international organizations and other stakeholders which could support its democratic nation building and development.

The manifestation of Mongolia's post-2000 foreign policy in terms of its balance of influence behaviour is its bilateral military engagement with the US, its re-establishment of military relations with Russia, its military engagement 
with other strategic states and institutions in Asia, and its continued relations with Beijing so as to indirectly balance China. ${ }^{34}$ In that sense, Mongolia has placed a priority focus on regional and global issues, particularly those concerning the Asia-pacific region. So far as Mongolia's approach towards regional and global issues is concerned, there is a commonality of interest between Mongolia and other countries of the world. Since Mongolia has established partnerships with neighbouring countries and many other countries around the world through open, peaceful and multi-faceted diplomacy, these partners have cooperated in Mongolia's development as well. Over the past two decades, Mongolian foreign policy irrespective of changes made in it, has actually been focussing on developing friendly and mutually beneficial ties "with states beyond its immediate/powerful neighbours." 35 This is in line with the Mongolian national interests, which give much attention to "the preservation of the Mongolian people and their civilization, the country's independence, territorial integrity, and relative economic independence." ${ }^{36}$ Therefore, Mongolia has been making serious efforts for ensuring security to its border as well as having "stable" relations with immediate and distant neighbours.

\section{Balancing Russia and China through "Third Neighbour" Policy}

Dierkes (2011) emphasizes that "the dominant stated theme of Mongolian foreign policy has been the so-called 'third neighbour' policy; that is, attempts by successive Mongolian administrations to build closer ties with partners other than Russia and China, its dominant neighbours." ${ }^{37}$ The "Third Neighbour" policy came into existence as a policy of balancing Mongolia's two geographic neighbours, resulting from the country's internal and external objectives as specified in the Concept of National Security and Concept of Foreign Policy. In one of his latest articles, Soni has highlighted the fact that Mongolia is now looking beyond its geographic neighbours and hence "today Mongolian diplomacy is indeed characterized by the "third neighbour' policy". ${ }^{38}$ The term "third neighbour" was generated in August 1990 by the visiting US Secretary of State James A. Baker while delivering a speech to support Mongolia's first move towards democracy aftermath the first free elections held same year in July. According to Soni (2012), such a new idea was immediately picked up and reinterpreted by the Mongolian elite and policy makers, who for centuries had never thought of anything beyond a pawn between the Russian and Chinese. Citing an American Mongolist he further elaborates that "though the term began to be used in Mongolian media and scholarly works, it was not reciprocated in the United States until the late 1990s when Alicia Campi, a well-known expert on Mongolian affairs reminded the American officials at the first American bilateral conference in Washington, 
DC to declare that their Mongolian counterparts could refer to the United States as a third neighbour". ${ }^{39}$

Simultaneously, Mongolian foreign policy had by then already affirmed that Mongolia will focus its attention on developing friendly relations with state beyond its geographic neighbours. The "third neighbour" policy, therefore, easily explains the "multipillarity, complexity and openness of Mongolia's foreign policy [which] undoubtedly attracted attention of the regional and world community, and the country's position on the international arena has been strengthened substantially". ${ }^{40}$ In 2012, during his interview given to Allen Wagner on the theme "Mongolia: Growth, Democracy, and Two Wary Neighbours" for The National Bureau of Asian Research, Alan Wachman commented that Mongolia's "third neighbour" approach "is driven most forcefully by geography." ${ }^{41}$ Since those states that are landlocked face monumental challenges to development, Mongolia too comes into this category as it is bounded by only two states-Russia and China who happen to be communist behemoths. Wachman feels that "by linking its security to a roster of states other than Russia and China, Mongolia has made its intention clear to act internationally with as much freedom as it can muster from constraints that Moscow or Beijing might wish to impose". ${ }^{42}$ Also both Russia and the China are still cautious of external powers, particularly the United States, setting down roots in states along their borders.

The motivational factor indicates that in order to loosen the pressure of Russia and China, Mongolian leaders have developed the "third neighbour" policy. This policy insists in creating new strategic alliances abroad without causing economic and commercial issues with the Russians and Chinese. In this vein, Mongolia maintains strong ties with the United States, the European Union, Japan, India and Australia, to name a few. These bilateral relations and cooperation are organized at all levels: business and trade, political and military. Economic vulnerability of Mongolia largely explains the important efforts of the Mongolian authorities to convince foreign countries to invest in Mongolia particularly in the infrastructure sector which the country needs a lot. ${ }^{43}$ Commenting on Mongolia's "third neighbour" policy Li Narangoa, though, gives a different point of view. ${ }^{44}$ According to her, "These powerful 'third neighbours' or 'comprehensive partners,' ironically all strongly influenced by the United States, are countries that Mongolia can rely on in its efforts to balance the power of its direct neighbours". ${ }^{45}$

Nonetheless, one crucial challenge faced by the Mongolian leadership is to achieve a balance of influence between their two neighbours - Russia and China by building on the strong economic and political competition in which they engage in Mongolia. Although Mongolia is trying to control the level of economic penetration of each of its two neighbours, any political, economic or commercial agreement with either of the two will certainly be counterbalanced by a similar 
agreement in magnitude with the other. At this point, Mathieu Boulugue feels that "Mongolia's increasing assertiveness could not have taken place without the implicit consent of its neighbours, who both play an underlying role in recognizing and respecting the country's sovereignty". ${ }^{46}$ From Moscow's and Beijing's point of view, the rationale behind the respect of Mongolia's sovereignty is thereby to maintain a strategic neutral space between them. ${ }^{47}$ However, the 2011 Foreign Policy Concept makes it clear that unlike Russia Mongolia's understanding of its relations with China has changed despite Ulaanbaatar's continued ties with Beijing. While the 1994 Foreign Policy Concept categorises relations with China and Russia as the state's principal foreign policy concern, the 2011Concept gives equal priority to Mongolia's relations with its third neighbours, particularly the United States. ${ }^{48}$

On the other hand, China's relations and influence over Mongolia increased mainly because after the disintegration of the former Soviet Union and the end of the Cold War, Mongolia's trade with Russia declined by 80 per cent. ${ }^{49}$ But Russia sought to rebuild strong relations with Mongolia, particularly in the late 1990 s to enhance its standing as a regional power. As a result, in 2000, the then Russian President Vladimir Putin made a landmark visit to Mongolia which was popularly welcomed in Mongolia as “countering China's influence". Since then there has been growth in Mongolia-Russia relations because Mongolia views its relationship with Russia as one of its foreign policy priorities. Thus the long term, stable development of good neighbourly, equal and mutually beneficial ties in all areas with Russia is perceived as essential in Mongolia. Synchronously, China cannot be ignored as Mongolia continues to have the long-term goodneighbourly relations and mutually beneficial cooperation with China on the basis of universally accepted norms and principles of international law. The fact that Mongolia's 2011 revised foreign policy concept discreetly identifies China as the country's largest security concern which has been reflected in Ulaanbaatar's post-2000 foreign policy relations, Chinese FDI in Mongolia in 2010 crossed over Russian FDI substantially. Thus, according to Backes, "even if Russian investment in Mongolia were to increase, it would have to grow at an unrealistic rate to genuinely challenge China's stranglehold on Mongolia's economy" 50 Campi too stresses that "although Mongolia is sensitive to Chinese activity in the mineral sector, it is willing to let China become a significantly larger supplier of oil products, at least in the short term, to break the back of its dependency on more expensive Russian petroleum products". ${ }^{51}$

There is no doubt that Mongolia's foreign policy is strongly affected by its two geographic neighbours. Indeed, when geography comes into play, every resource has to go through either China or Russia, and therefore, every deal including in the mining sector signed with one neighbour might provoke the other neighbour 
into accusing Mongolia of favouring its opponent. ${ }^{52}$ However, as Wilbrink sums up, "the status quo indicates that most of the exports go through China." Nevertheless, the fact remains that being a land-locked country in a geopolitical set up any future external threat to Mongolia's security by whatever means it is, could be related directly or indirectly with either or both of its two neighbours. ${ }^{53}$ However, in the democratic era the most important factor in Mongolia's foreign relationship including with China and Russia is tied to economics not politics, ${ }^{54}$ and hence not only China but also Russia would continue to occupy important place in Mongolia's foreign relations.

\section{Conclusion}

The main purpose of foreign policy of a country is to conduct foreign relations to the best possible advantage to serve its national interests. Mongolia too is not an exception. Democratic reforms and economic restructuring following the Soviet collapse provided the best ever opportunity for Mongolia to adopt its own "Multi-Pillar" foreign policy in 1994, thus safeguarding the country's security and independent existence in the multi-polar world. The impact of foreign policy on the two geographic neighbours was that it articulated a new strategy to balance Mongolia's relations with Russia and China that is known as the "third neighbour" policy. After twenty years of democracy, when Mongolia felt it necessary to review its regional security status and also the "third neighbour" policy, it revised its existing foreign policy and in 2011 came out with a new Concept of Foreign Policy to guide the nation for its future foreign relations with Russia, China, and the other countries of the world. Nobody can deny that in the democratic era economics has overpowered politics and so China does not seem to let loose the opportunity in dominating Mongolia economically while compared to that of Russia. But both Russia and China will continue as significant partners of Mongolia in foreign policy matters irrespective of the extent of their economic dominance at least for the foreseeable future. Mongolia, on the other hand, will continue with its most important task of balancing these two neighbours to avoid the repetition of Cold War situation in its territory. 


\section{Endnotes}

1. Farah Naaz (2012) "Role of National Interest", in Rumki Basu (ed.), International Politics: Concepts, Theories and Issues, New Delhi: Sage, pp. 53-57.

2. See Felik Gross (2009), Foreign Policy Analysis, New York, pp. 4748.

3. T.K. Balakrishnan (2010), Foreign Policy of Mongolia: Problems and Paradoxes, Delhi: Mohini Publishers, p.19.

4. Embassy of Mongolia in the United Kingdom, Mongolia's Foreign Policy Concept, [Online: web] Accessed 11 September 2014, URL: http://www.embassyofmongolia.co.uk/index.php?option=com_cont ent\&view=article\&id=59\&Itemid=76\&lang=en

5. Ministry of External Relations of Mongolia (2000), Mongolian Foreign Policy Blue Book, Ulaanbaatar: The Policy Planning and Coordination Department, p. 7.

6. D. Banerjee, D. (1992), "Neither War Nor Peace", World Focus, vol. 13, nos. 11-12, p.11.

7. See Address by N. Enkhbayar (2008), "Mongolia's Foreign Policy: Efforts towards Regional Peace and Security", Mongolian Journal of Strategic Studies, pp. 6-7.

8. D. Bayarkhuu (2003), "Post Communist Transition and Common Ground: A Mongolian Perspective", The Mongolian Journal of International Affairs, no. 10, p. 67.

9. Sharad K. Soni (2003), Mongolia between Russia and China: Emerging Equation, Kolkata: Maulana Abdul Kalam Azad Institute of Asian Studies, p.64.

10. J. Enkhsaikhan, J., (2000) "Single State NWFZ: From Concept to Practice", The Mongolian Journal of Strategic Studies, no. 2, p.19.

11. Article 1 of the 1992 constitution clearly states that "the fundamental purpose of the State activities is the ensurance of democracy, justice, freedom, equality, national unity and respect for law", See The Constitution of Mongolia (1992), Ulaanbaatar.

12. This has been mentioned in Article 10 of the 1992 constitution which exclusively deals with the foreign policy matters.

13. Sharad K. Soni (2006), "Mongolia's Security Thinking and Outside World: A Reappraisal", Bimonthly Journal of Mongolian and Tibetan Current Situation, vol. 15, no.6, pp. 27-39.

14. Government of Mongolia (1998), Mongolian Defence White Paper, 1997-1998, Ministry of Defence, Ulaanbaatar, p.29. 
15. Alan J.K. Sanders (1987), Mongolia: Politics, Economics and Society, London: Frances Pinter, p.272.

16. Sharad K. Soni (2008), "Post-Cold War Identity of Mongolia: Strategic Concerns", in P. L. Das (ed.), Emerging Asia in Focus: Issues and Problems, Delhi: Academic Excellence, p. 420.

17. Sharad K. Soni (2001), "Mongolia's Foreign Policy Priorities," Himalayan and Central Asian Studies, vol. 5, no.1, p. 57.

18. Alicia J. Campi (1999), "Moving Mongolian Nomadism intio the 21st Century: Cultural and Ecological Preservation Coupled with Economic Vitality and National Security", Mongolica (Ulaanbaatar), vol. 9 , no. 30, p. 550.

19. Sarah Telford (2006), "To What Extent Does Post-1990 Mongolia Pursue an Independent Foreign Policy?", Bimonthly Journal of Mongolian and Tibetan Current Situation, vol. 15, no.3, p. 56.

20. See Ts. Batbayar and Sharad K. Soni (2007), Modern Mongolia: A Concise History, New Delhi: Pentagon Press, pp.121ff.

21. Embassy of Mongolia, Vienna (2011), "Mongolian Foreign Policy Draft Resolution Submitted", 13 January, [Online: web] Accessed 16 April 2011, URL: http://www.embassymon.at/news/news_258. html

22. President of Mongolia (2012), The Office of the President of Mongoliua, Public Relations \& Communications Division, "Remarks by H.E. Mr. Tsakhia Elbegdorj, President of Mongolia, at a Reception with Diplomatic Corps in Ulaanbaatar on the Occasion of the New 2012 Year", 9 January, [Online: web] Accessed 16 April 2013, URL: http://www.president.mn/eng/newsCenter/viewNews. php?newsId $=653$

23. Jeffrey Reeves (2012), "Mongolia's evolving security strategy: omni-enmeshment and balance of influence", The Pacific Review, vol. 25 , no. 5 , p. 589 .

24. Ibid, p. 601.

25. See Ministry of Foreign Affairs (2011), Government of Mongolia, Concept of Mongolia's Foreign Policy, 21 February, [Online: web] Accessed 16 April 2013, URL: http://www.mfa.gov.mn/ index.php? option $=$ com_content $\&$ view $=$ article $\& i d=79 \% 3 \mathrm{Ai}-$ \&catid=36\%3A2009-12-20-21-52-14\&Itemid=55\&lang=en

26. Sharad K. Soni (2012) "Looking beyond Geographic Neighbours : Post-Soviet Mongolia's "Third Neighbour Policy", in Suchandana Chatterjee, Anita Sengupta and Sushmita Bhattacharya (eds.), Eurasia: Twenty Years After, Delhi: Shipra Publications, p.488. 
27. Ibid.

28. See Enkhbayar (2008), "Mongolia’s Foreign Policy”, pp. 6-7.

29. Ibid.

30. Oyun Sanjaasuren (2008), "Mongolia's Foreign and Security Policy at the Dawn of the New Century", Mongolian Journal of Strategic Studies, no. 12, p.14.

31. Allan M. Wachman (2009), Mongolia's Geopolitical Gambit: Preserving a Precarious Independence While Resisting "Soft Colonialism”, EAI Fellows Program Working Paper Series 18, Seoul: The East Asia Institute, p.8.

32. Soni "Mongolia's Foreign Policy Priorities", p. 57.

33. Alicia J. Campi (2005), "Mongolia in Northeast Asia-The New Realities", The Mongolian Journal of International Affairs, no.12, p.51.

34. Reeves, "Mongolia's evolving security strategy", p.590.

35. Brandon Joseph Miliate (2009), "India's Role in Mongolia's Third Neighbor Policy", Independent Study Project (ISP) Collection. Paper 802, [Online: web] Accessed 17 April 2010, URL: http:// digitalcollections.sit.edu/isp_collection/802.

36. Ibid.

37. Julian Dierkes (2011), "Mongolia's 'third neighbour' policy and its impact on foreign investment", 15 February, East Asia Forum, [Online: web] Accessed 16 April 2012, URL: http://www. eastasiaforum.org/2011/02/15/mongolias-third-neighbour-policyand-its-impact-on-foreign-investment/

38. Soni, "Looking beyond Geographic Neighbours", p. 489.

39. Alicia J. Campi (2010), "Mongolia's Foreign Policy Vision for Eurasia," Speech at a Jamestown Foundation Seminar, 10 November (unpublished), cited in Soni, "Looking beyond Geographic Neighbours", p.489.

40. A. Tuvshintugs (2010), "Mongolia's National Security: Past, Present and Future Perspectives," in K. Warikoo and Sharad K. Soni, eds. Mongolia in the 21st Century: Society, Culture and International Relations, New Delhi: Pentagon Press, p.76.

41. The National Bureau of Asian Research (2012), "Mongolia: Growth, Democracy, and Two Wary Neighbors": An Interview with Alan Wachman, Interview taken by Allen Wagner, 3 May, [Online: web] Accessed 11 September 2014, URL: http://www.nbr.org/research/ activity.aspx?id=245\#.Uic9tzbI1 K0

42. Ibid. 
43. MIT Sloan Archive (2012), "Mongolia's Foreign Policy: The Quest of the 3rd Neighbor", 18 March, [Online: web] Accessed 10 October 2014, URL: http://mitsloanblog.typepad.com/natural resources/2012/03/mongolian-foreign-policy-the-quest-of-the-3rdneighbor.html

44. See Li Narangoa (2009), "Mongolia and Preventive Diplomacy: Haunted by History and Becoming Cosmopolitan", Asian Survey, vo. 49 , no. 2 , pp. $358-379$.

45. Ibid, p.376.

46. Mathieu Boulègue (2012), "Landlocked Assertiveness: Mongolia's Restructured Realism in a More Complex World", Central Asia Economic Paper, vol.4, no.10, p.6.

47. Ibid.

48. Reeves, "Mongolia's evolving security strategy", pp.602-3.

49. Nomin Lhagvasuren (2000), "Russia Seeks to Restore Position in Mongolia as Most Favored Neighbor", 16 November, [Online: web] Accessed 11 September 2014, URL: http://www.eurasianet.org/ departments/insight/articles/eav111700.shtml.

50. Backes, "China at the Gates".

51. Alicia J Campi (2013), "Sino-Mongolian oil deal undercuts Russian role", Online Asia Times, 15 May, [Online: web] Accessed 12 October 2014, URL: http://www.atimes.com/atimes/China_Business/CBIZ01-150513.html

52. Benny Wilbrink (2013), "Mongolia: from Puppet to Puppet Master?". 19 May, [Online: web] Accessed 10 October 2014, URL: http://www.upflund.se/utrikesperspektiv/2013/5/19/mongolia-frompuppet-to-puppet-master.html\#.Ue_KKtIzhGY

53. Sharad K Soni (2009), "Security Factor in Mongolia-China Relations", World Affairs, vol.323, no.18, p.39.

54. Alicia J. Campi (2012), "Mongolia's Strategic Views on the Roles of Russia and China in its Future Development", Mongolian \& Tibetan Quarterly, vol. 21, no. 2, p. 92. 